\title{
The Use of Pair Work to Reduce Speaking Anxiety in an EFL Classroom
}

\author{
Mutiara Putri Aulia, Nenden Sri Lengkanawati, Rojab Siti Rodliyah \\ English Education Department \\ Universitas Pendidikan Indonesia \\ Bandung, Indonesia \\ mutiarapaulia@upi.edu
}

\begin{abstract}
Anxiety in speaking is one of the common obstacles in learning English as a foreign language which leads students to neglect the opportunity to speak English in the classroom. To help students in reducing speaking anxiety, teachers need to find a suitable teaching strategy. Based on the issue, this study reports how to pair work activity implemented in an EFL classroom helps teachers in reducing speaking anxiety and the role of pairworking activity in reducing speaking anxiety among EFL students. This study employs three instruments which are questionnaires, interviews, and observation. As a result, pair work successfully lessened students' speaking anxiety by promoting interaction between students and the opportunity to speak where the less anxious students help the anxious ones in pronouncing certain words and inform the suitable vocabularies.
\end{abstract}

Keywords: EFL students, foreign language speaking anxiety, pair work activity

\section{INTRODUCTION}

Oral communication skill in English language learning is considered as the most required skill especially in the field of professionalism. Considering the importance of oral communication skills among society nowadays, EFL teachers should be aware of this issue by preparing several teaching strategies to improve students' confidence and decrease speaking anxiety in an EFL classroom.

However, Hamzah and Ting (2010) find out that students usually feel insecure and have problems communicating and express themselves using the target language which shows the fact that not all students have the courage to speak in front of their classmates. Several problems obstruct students to speak. Anxiety is one of the results of daunting aspects in learning a foreign language (Oxford, 1999 in S. Gabarre, Gabarre, Din, Shah, \& Karim, 2016). To add, Aydin (2008, as cited in Shabani, 2012) believes that anxiety is a significant factor that affects language learning. Moreover, Ganesh, Athilakshmi, Maharishi, and Maya (2015) believe that anxiety can influence everyone's life. Hence, teachers should provide a suitable teaching strategy to decrease anxiety among students

Considering anxiety as the main factor in improving speaking skills, teachers need to provide a teaching strategy whose characteristics can obstruct the causes of speaking anxiety. Pair work allows students to have a chance to work with another student to reach the same goal in the learning activity. According to Kondo and Ying-Ling (2004), having a pair can help anxious students in controlling their anxiety and understanding each other. In this section, the researcher provided one less anxious student to be paired with one student who was considered as anxious. It was expected to enable the transference of knowledge and confidence from the relaxed students to anxious students. It is in line with Storch and Aldosari (2013) who conducted a study where one high proficiency learner was paired with one low proficiency learner. One of the results of pairing the students was that the pair classified into an Expert-Novice pattern as it is one of the dyadic patterns written by Storch (2002). In the end, speaking anxiety among EFL students is hopefully reduced. Students' anxiety in speaking ability is expected to decrease and increase students' self-confidence since pair work offers a better occasion to speak than working in a group that consists of three or more students.

Based on the issue, this study aims to (1) to know the level of anxiety among EFL students in a classroom and (2) find out how to pair work decreases the speaking anxiety among students in a classroom.

Anxiety is often found as a problem among students in learning language especially foreign language. There are numerous statements regarding the definition of anxiety since it is related to human psychological issues. As mentioned before, Atkinson (2001) sees anxiety as an uncomfortable feeling which includes fears and worries. Thus, anxiety in speaking can be defined as being scared or worried to convey ideas or feelings. In the EFL classroom, it is predictable that the number of anxious students is higher than the ESL classroom as Occhipinti (2009) states that to speak a foreign language is a challenging activity and foreign language students cannot fully express their intelligence or personality. To make it more understandable, Horwitz, Horwitz, and Cope (1986) elaborate on the components consisting of three in foreign language anxiety which are communication apprehension, test anxiety and fear of negative evaluation. 
Communication apprehension is the fear that associates with real or anticipated communication with other people (McCroskey, 2001). Meanwhile, test anxiety is the fear which is associated with the experience of academic activities and evaluation. It is in line with Shabani (2012) who says that test anxiety has a relation to academic evaluation. The last component is a negative evaluation. It is similar to the test anxiety. However, this kind of anxiety does not only occur in a test-taking situation but also any social context (Horwitz, Horwitz and Cope, 1986). According to Liu (2007), there are three factors in reducing speaking anxiety.

\section{More exposure to oral English}

2. More practice

3. Building up confidence

Meanwhile, pair work can be defined as working with a partner. This definition is similar to Richards and Schmidt (2013) who define pair work as a learning activity that requires students to work in pairs. To make it specific, four dyadic patterns are classified by Storch (2002). The patterns include collaborative, dominant-dominant, dominant-passive and the last is expert-novice. According to Watcyn-Jones and HowardWilliams (2002), Zohairy (2014), Tran (2001) and Jones (2007), there are five characteristics and benefits of pair work which are expected to reduce the three factors in reducing speaking anxiety.

\section{METHODS}

\section{A. Research Design}

This study used a qualitative method in the form of the teacher as a researcher. According to Thurlow (2002) in Sugiyono (2017), qualitative research is used to gain in-depth information regarding the topic of the research which is analyzed narratively.

\section{B. Site and Participant}

This study was conducted in a junior high school in Bandung which involved 31 students in one classroom. There were three main instruments used to obtain the data of the study which were questionnaires, observation, and interviews. Also, this study employed field notes in the observation sheet.

\section{Data Collection}

Several instruments were used in collecting the data. Those instruments were observation, questionnaire, interview, and test performance. Observation, questionnaire, and interview were divided into two sections while test performance was conducted three times during the research.

\section{Data Analysis}

Data analysis was gathered from several instruments which were questionnaires, observation, and interviews. The result of the analysis indicated that students experienced anxiety on different levels. The second section was applied after conducting pair work, the analysis of data from the questionnaire would have the same system as the first section. Moreover, descriptive statistics were used to analyze the data. Before classifying the students into levels of anxiety, Likert's 5-graded scale was employed as a tool of measurement which has five points, strongly-agree, agree, neutral, disagree and strongly disagree. In the observation section, videotaping was utilized which means that the researcher recorded the situation which happened in the classroom especially when the anxious students came forward to perform. Later, the researcher analyzed the data from the interview. The researcher took note and recorded everything in the section using the voice recorder to avoid mistakes in collecting the data and transcribed every word based on the interview section.

\section{FINDINGS AND DISCUSSION}

\section{A. Abbreviations and Acronyms}

Based on the first questionnaire which was administered to the students, the researcher found out that only two students who were considered as "relaxed" and one student was categorized as "very relaxed". Meanwhile, there were 7 students considered as "very anxious" students, 11 "anxious" students and there were 10 students categorized as "mildly anxious" students. Based on the fact that there were only 3 students who were expected to take the role as "expert" which were the less anxious learners according to the theory of dyadic pattern by Storch (2002), the researcher paired them with another three students who were categorized as "very anxious", "anxious" and "mildly anxious". These three students who had anxiety in speaking English were chosen to be the participants of the research.

After conducting pair work as a teaching strategy, the researcher administered the second questionnaire to measure students' level of speaking anxiety. Based on the second questionnaire administered to the students, they successfully decreased the speaking anxiety they have experienced in learning English. Their anxiety scores before being paired were 94, 121 and 124 where each student was categorized as "Mildly anxious", "Anxious" and "Very anxious." After conducting pair work in the classroom, the researcher found that their speaking anxiety has been significantly decreased to the "Relaxed" category in their second questionnaire. Each student reached the score 68,83 and 81 . Based on the data from the interview, students stated that they suffered speaking anxiety due to the fear of making mistakes in pronunciation and being laughed by their classmates.

Based on the interview, all participants admitted that they were afraid of being mistaken in learning English due to the difficulty of pronouncing English vocabulary. According to Jin (2007) and Young (1991), the students could be failed in the learning process because of the fear of making mistakes and verbal error. Moreover, according to Balem (2009), students are anxious to speak due to the lack of vocabulary and having a problem in pronouncing.

At first, they also began to be anxious towards the thought of being laughed by their classmates. Considering these two main factors, it can be concluded that students are afraid of negative evaluation either it comes from the teacher or the 
environment. In line with Horwitz, Horwitz, and Cope (1986) who believe that students are quite sensitive towards the evaluations they get whether it is real or imagined. Moreover, in the interview section, two students admitted that the fear of making mistakes caused them to give less contribution to English class.

After implementing pair work to the class, all participants confessed that they had their speaking anxiety lower than they used to have before getting the treatment. According to the participants, pair work helped them to gain more vocabulary and pronounce English words correctly. The participants' knowledge and confidence were increased by their partners which are similar to the statement of Achmad and Yusuf (2014) who claim that pair work enables students to improve confidence.

The progress of reducing students' speaking anxiety in an EFL classroom through pair work activity was gradually successful. Students did not indicate the reduction of speaking anxiety in a short time. To monitor the progress, the researcher observed students' behaviors through the theory of physical behavior of anxious students written by Suleimenova (2013) in Table I below.

TABLE I. PHYSICAL BEHAVIOR OF ANXIOUS STUDENTS

\begin{tabular}{|l|l|}
\hline No & \multicolumn{1}{|c|}{ Physical Behavior of Anxious Students } \\
\hline 1. & Squirming \\
\hline 2. & Fidgeting \\
\hline 3. & Playing with hair or clothing \\
\hline 4. & Touching object nervously \\
\hline 5. & Stuttering or stammering \\
\hline
\end{tabular}

In the first meeting, when they began to be paired with a partner, some students still seemed to be shy and afraid whenever the teacher asked them to come forward to present their assignments. They seemed to constantly read or held their books or notes, avoided eye contact and were very stuttering. In the second meeting, students still could be seen a little bit nervous and still held their books or notes but they did not sound stammering or stuttering as often as they used to be in the first meeting. In the last meeting, they began to relax by speaking without holding notes or books. They only saw the notes or books for once or twice to remind them about some keywords. Moreover, they also did not squirm as often as they used to.

\section{B. Pair Work in Reducing Speaking Anxiety}

According to observation sheets of pair work characteristics and students' physical behaviors, the students successfully reduced speaking anxiety by working with partners. Moreover, all characteristics of pair work slowly occurred in all participants. During the interview section, all participants agreed that their partner contributed to making them gain more knowledge about English words and corrected how they pronounced vocabularies before they had to come forward to present their assignments. This fact is in accordance with Maher (2011) who admits that pair work is a teaching strategy that could introduce students to language items and functions.
Pair work also stimulates students in language production (Zohairy, 2014). This fact could happen due to the interaction between two students during the process of learning.

Another characteristic in pair working is the opportunity to speak. Implementing pair work in the classroom allows learners to practice the language (Harmer, 2007). This statement is in line with Achmad and Yusuf (2014) who claim that pair working activity enables students to have more chance to speak English in the classroom which has been admitted by S1 where he confessed in the interview section that he gained more opportunity to speak in pair working than in a group which consists of 3 people or more.

Moreover, Liu (2007 p. 132) stated that having more exposure to oral English is one of the three main factors in decreasing speaking anxiety among students. Furthermore, cooperative learning and interaction were depicted while students were working together as Wichadee (2010) stated that a supportive environment leads students to be less stressed. Thus, pairing students to improve one student's performance is quite recommended.

Having more practice in oral language also can be seen in a pair of work activities. Based on the findings of this study, providing a partner for anxious students also gives them more opportunities to practice in using English before coming to the classroom to perform. This in line with what Storch (2002) has stated that pair work provides speaking practice among learners. Working with only one student could give them more opportunity to speak words in English as some anxious students preferred to work in a pair considering the opportunity to speak is bigger than group work. Liu (2007) highlights that one of the three main factors to lessen anxiety in speaking is doing more practice which is similar to students' responses in working in pairs.

In the interview section, all participants admitted that their level of self-esteem is higher than before they received the treatment which is suitable for Liu (2007 p. 132) who claimed that pair work helps students to build up confidence. Pair work activity stimulates students' confidence through their partner by telling them how to pronounce the words correctly. In this case, the participants were not afraid to speak the words due to the knowledge they have received from their partner.

The private section in working with a pair did not always occur in all meetings since students seemed to interact and have a little discussion with another pair. In the interview section, they admitted that they still interacted with another pair. However, in the next meetings, the students began to have a private section by focusing only on their pair.

\section{CONCLUSION}

This study investigated pair work activity as a teaching strategy to help anxious students in reducing speaking anxiety in an EFL classroom. The conclusion is drawn based on the findings obtained from the instruments (questionnaire, observation, and interview). 
Firstly, based on the first questionnaire, it was found that from 31 students there was one student who was considered as very relaxed which indicates $3 \%$ in the classroom. Meanwhile, there were $6 \%$ relaxed students. For the anxious students, it was found that $32 \%$ of students were in the category of mildly anxious, $36 \%$ anxious students and $23 \%$ very anxious students. In more addition, according to the interview, the factors which contributed to speaking anxiety were the fear of being laughed by friends. Students were also afraid of making mistakes which lead the anxious students to have the fear of negative evaluation.

Secondly, after conducting pair work activity in the classroom for three meetings, it effectively helped students to lower their anxiety towards speaking a foreign language. These findings were gained from the two observations and interview sections. From the observation on the physical behavior of anxious students, all participants slowly lessen their anxiety behavior while speaking in front of their classmates. In line with the first observation, the second observation which focused on the pair work characteristics towards the teaching and learning activity showed that pair work as a teaching strategy could increase students' self-esteem in learning English. Additionally, students also revealed in the interview section that they got more opportunity to practice speaking English with their partner and the interaction between students was also contributed to lowering speaking anxiety among students.

\section{REFERENCES}

Achmad, D., \& Yusuf, Q.Y (2014). Observing pair-work task in an English speaking class. International Journal of Instruction, 7(1), 151-164.

Atkinson. (2001). Pengantar psikologi. Jakarta: Interaksa

Balem, S. (2009). The source of foreign language speaking anxiety and the relationship between proficiency levels of degree of foreign language speaking anxiety. (Unpublished master's thesis), Bilkent University, Ankara.

Gabarre, S., Gabarre, C., Din, R., Shah, P., \& Karim, A. A. (2016) Addressing foreign language learning anxiety with facebook. Creative Education, 7, 93-104. doi: 10.4236/ce.2016.71010.

Ganesh, K. J., Athilakshmi, R., Maharishi, R. \& Maya, R. (2015). Relationship between fear of negative evaluation and anxiety. The International Journal of Indian Psychology, 3(1), 74-80.

Hamzah, M. H., \& Ting, L. Y. (2010). Teaching speaking skills through group work activities: A case study in SMK Damai Jaya. Universiti Teknologi Malaysia. Retrieved

http://eprints.utm.my/10255/2/Lu_Yee_Ting.pdf
Harmer, J. (2007). The practice of English language teaching. New York : Longman.

Horwitz, E.K., Horwitz, M.B., \& Cope J. (1986). Foreign language classroom anxiety. The Modern Language Journal, 70, 125-132. doi: 10.1111/j.1540-4781.1986.tb05256.x

Jin, Y. H. (2007). Investigating the difficulties in speaking English for academic purposes-A case study of an overseas Chinese student. SinoUS English Teaching, 4(4), 24-28.

Jones, L. (2007). The student-centered classroom. New York, NY: Cambridge University Press.

Kondo, D.S., \& Ying-Ling, Y. (2004). Strategies for coping with language anxiety: The case of students of English in Japan. ELT Journal, 58 , 258-265. doi: 10.1093/elt/58.3.258

Liu, M. (2007). Anxiety in oral English classrooms: A case study in China. Indonesian JELT, 3(1), 119-137.

Maher, K. M. (2011). Intricacies of pair work-surveys and research. The Bulletin of Keiwa College, 20, 15-32.

McCroskey, J. C. (2001). An introduction to rhetorical communication. Boston, MA: Allyn \& Bacon.

Occhipinti, A. (2009). Foreign language anxiety in in-class speaking activities: Two learning contexts in comparison. The Department of Literature, Area Studies and European Languages: The University of Oslo.

Richards, J. C., \& Schmidt, R. W. (2013). Longman dictionary of language teaching and applied linguistics. New York: Routledge.

Shabani, M.B. (2012). Level and sources of language anxiety and fear of negative evaluation among Iranian EFL learners. Theory \& Practice in Language Studies,. 2(11), 2378-2383. doi: 10.4304/tpls.2.11.23782383

Storch, N. (2002). Pattern of interaction in ESL pair work. Language Learning, 52(1). 119-158. doi: 10.1111/1467-9922.00179

Storch, N., \& Aldosari, A. (2013). Pairing learners in pair work activity. Language Teaching Research, 17(1), 31-48. doi: $10.1177 / 1362168812457530$

Suleimenova, Z. (2013). Speaking anxiety in a foreign language classroom in Kazakhstan. Procedia-Social and Behavioral Sciences, 93, 1860 1868. doi: 10.1016/j.sbspro.2013.10.131

Sugiyono. (2017). Metode Penelitian Kualitatif. Bandung: ALFABETA.

Tran, L. (2001). Using pair work and group work in teaching writing. Teacher's Edition, 5, 22-28.

Watcyn-Jones, P. \& Howard-Williams, D. (2002). Pair work 1. Longman and Pearson Education

Wichadee, S. (2010). Coopertive learning approach: A successful way of reducing learning anxiety in an EFL class. International Journal of Education Khon Kaen University, 33(3), 1-5.

Young, D.J. (1991). Creating a low-anxiety classroom environment: What does language anxiety research suggest?. The Modern Language Journal, 75(4), 426-439. doi: 10.1111/j.1540-4781.1991.tb05378.x

Zohairy, S. (2014). Effective pair work strategy to enhance saudi preintermediate college students' language production in speaking activities. European Scientific Journal, 10(2), 50-63. 